\title{
A HISTORICAL GEOGRAPHY OF JEWISH SETLLEMENT IN GEORGIA (THE CAUCASUS)
}

\author{
Revaz Gachechiladze ${ }^{1}$
}

\begin{abstract}
The presence of the Jewish population in Georgia and its peaceful coexistence with the local people has more than two millennia history. More or less systemic sources about the spatial aspects of their presence in Georgia exist only from the second half of the $19^{\text {th }}$ century. The paper discusses the historical geography of the Jewish population in the $19^{\text {th }}-20^{\text {th }}$ century with the emphasis on their settlement pattern in the 1920s using for that purpose a detailed Population Census carried out in 1926.
\end{abstract}

Keywords: Jews of Georgia, Georgian Jews, settlement pattern, Population Census of 1926.

\section{Introduction}

If someone will search the internet about "Jewish settlement" the first things that will appear on the screen will be "Jewish settlement in Palestine" or "Jewish settlements in the West Bank".

But this paper's aim is more mundane - to describe the geographical pattern of Jewish settlement in Georgia (the Caucasus) where the Jews used to live peacefully for centuries along with their neighbours of ethnic Georgian or other origins. Although being a small share of the entire population of Georgia the Jews were significant in this country's history and geography. There were several small towns and rural communities in Georgia where the Jews constituted a significant part of the population before their majority left for Israel or, to much less extent, for the USA and the EU states in the last decades of the $20^{\text {th }}$ century.

Although some authors touch upon the issue of the distribution of Jewish population on the territory of historical Georgia (Mamistvalishvili, 1995; Khananashvili, 2002-3; Baazova, 2007; Lerner, 2008), the issue has not been studied from a geographical point of view. Therefore, the major topic of the paper is to analyze the geographical features of a relatively recent, but already historical pattern of settlement of Jews in Georgia. For that reason, the published materials of the first Population Census carried out in the Soviet Union in 1926 has been used.

The term "Georgian Jews" (commonly known as "uria " in Georgia before the $20^{\text {th }}$ century, and later as "kartveli ebraeli") describes a distinctive subgroup of the people of Judaic faith with Georgian vernacular while the term "Jews of Georgia" concerns the Jews of all the subgroups residing in this country. The majority of the Jews residing in Georgia were Georgian-speaking, especially in the city of Kutaisi, small towns, and rural area. Ashkenazi Jews, constituting about a third of the total in 1926, inhabited the largest urban centers (Tbilisi, Batumi) of the country. Jews had traditional congregations and synagogues in several towns, townships, and villages of Georgia.

The settlement network of the Jews in Georgia dramatically diminished in size from the late 1960 s and practically ceased to exist by the end of the $20^{\text {th }}$ century. A

\footnotetext{
${ }^{1}$ Department of Human Geography, Ivane Javakhishvili Tbilisi State University, Tbilisi, Georgia. E-mail: revazg@gmail.com
} 
small community remains today, mostly in the capital of Georgia, Tbilisi. The places where the Jews used to live still preserve artefacts indicative of their presence - most notably synagogues and cemeteries.

\section{The Jews in Georgia before the $20^{\text {th }}$ century}

The presence of the Jews in Georgia is evident from Georgian historical sources. A medieval chronicle attributes the arrival of the first Jews in Mtskheta, the ancient capital of Kartli (Eastern Georgia), to the time of the sacking of Jerusalem by Nebuchadnezzar II of Babylon in the $6^{\text {th }}$ century BCE (Kartlis tskhovreba,1955,1516). Apart from this rather mythological information, there are more reliable sources as well, e. g. a document of 1260 testifies that a Georgian Christian nobleman bought a village in the central part of Kartli from a group of vendors among whom was a person of Judaic faith (Kartuli istoriuli, 1984, 147). That suggests a Jew could own agricultural land (with serfs!) in medieval Georgia. On the other hand, many historical sources indicate the existence of serfs of Judaic faith dependent on Christian secular and spiritual feudal lords (Mamistalishvili,1995, 297; Baazova, 2016, 443).

During a long coexistence with the local people of Georgia, the mother tongue of Jews became Georgian. Most probably such linguistic assimilation had started from the earliest times of the Jewish settlement in Kartli. The spoken language of Georgian Jews contains a limited number of Hebrew words but practically does not differ from the standard Georgian (kartuli) language. It ought to be said that Georgian language differs from all the languages in the Caucasus and the Middle East: it belongs neither to Indo-European, nor to Semitic or Altaic (Turkic) linguistic families but to Kartvelian linguistic family embracing a handful of languages the Georgian proper (kartuli) being the dominant among them. For more than 15 centuries Georgian language uses a specific alphabet. These circumstances meant that the Jewish community which had adopted Georgian as vernacular became rather "different" from the other communities of their kin.

The Georgian Jews had a long history of coexistence with ethnic Georgians, but, apart from rare cases, didn't get assimilated with them and preserved their faith. A situation of an interethnic and interreligious symbiosis was peculiar to medieval Georgia and it continued later on. During feudalism which lasted in Georgia till the early $19^{\text {th }}$ century, a large part of the Jews of this country were engaged in agriculture, but many of them were active in trade and financial operations. These economic niches were avoided by ethnic Georgian nobility and peasants of the Orthodox Christian faith (Greek rite) at least till the second half of the $19^{\text {th }}$ century: the tradesmen in ancient Georgia were almost entirely the representatives of peoples of different faiths, predominantly Armenians and Jews.

The first Ashkenazi Jews arrived in Georgia from European part of the Russian Empire following the annexation by the latter of this country in the first decades of the $19^{\text {th }}$ century. The Caucasus was outside of the Pale of settlement for the Jews established in the Russian Empire by Empress Catherine II in 1791 and was accessible to European Jews to come and settle there. Ashkenazi Jews settled mostly in Tiflis ${ }^{2}$.

\footnotetext{
${ }^{2}$ Tiflis is a Persian pronunciation of an original Georgian place name Tbilisi, adopted in Russian and other languages. Tiflis was used until 1936 when the usage of Tbilisi became official in the USSR and later adopted elsewhere.
} 
Tiflis, being the seat of the Russian viceroy of the Caucasus and major administrative, commercial, and cultural center of the region attracted people from European parts of the Russian Empire and Europe proper. Some were Ashkenazi Jews, who became active in many spheres of the economy. The labor qualities of their artisans were in high demand for the Russian bureaucracy, for officers, the Georgian nobility, and Armenian bourgeoisie. In Tiflis "Jews were the best cobblers and tailors" (Jones, 2005,163). Georgian Jews started to move to Tiflis, mostly from the towns of Akhaltsikhe and Tskhinvali, later than Ashkenazi Jews, approximately by the mid- $19^{\text {th }}$ century. They avoided competition with local Armenian merchants in Tiflis (Mamistvalishvili, 1995, 111).

Information about the distribution of the Jewish population on Georgia's territory could be traced only from the second half of the $19^{\text {th }}$ century when in Georgia, then a part of the Russian Empire, local authorities started to collect information about the population and its ethnic and religious structure (e.g. Sbornik svedenii, 1880). According to the data of the First General Population Census of the Russian Empire of 1897 (Pervaya vseobshchaya, 1905) there were 16,716 persons of Judaic faith in Tiflis and Kutaisi provinces (gubernii) covering, respectively, eastern and western parts of Georgia. Kutaisi province comprised Batumi region (Batumskaia oblast', i.e. Adjara) and Sokhumi district (Sukhumski okrug, i.e. Abkhazia). Jews accounted for 1.28 percent of the total population of Georgia in 1897 (table 1).

Table 1. People of Judaic faith in Georgia in 1897

\begin{tabular}{|c|c|c|c|}
\hline $\begin{array}{c}\text { Administrative-territorial units } \\
\text { and their centers }\end{array}$ & $\begin{array}{c}\text { Jewish } \\
\text { ("evreiski") } \\
\text { speaking }\end{array}$ & $\begin{array}{l}\text { Georgian } \\
\text { speaking }\end{array}$ & Total \\
\hline Tiflis province & $\mathbf{5 0 7 9}$ & $\mathbf{4 1 5 8}$ & $\mathbf{9 2 3 7}$ \\
\hline of them in the city of Tbilisi & 2868 & 411 & 3279 \\
\hline Kutaisi province & $\mathbf{5 7 5 8}$ & $\mathbf{1 7 2 1}$ & $\mathbf{7 4 7 9}$ \\
\hline of them in the city of Kutaisi & 3410 & 38 & 3448 \\
\hline Batumi region & 1053 & 51 & 1104 \\
\hline of them in the city of Batumi & 1043 & 51 & 1094 \\
\hline Sokhumi district & 135 & 14 & 149 \\
\hline of them in the city of Sokhumi & 134 & 9 & 143 \\
\hline
\end{tabular}

Source: Pervaya vseobshchaya, 1905, pp.107-124

The Census of the Russian Empire of 1897 lacked a question about ethnicity and not always correctly identified mother tongue. That was especially apparent in the case of Kutaisi province where, according to the 1897 Census, the mother tongue of 77 percent of the population of Judaic faith presumably was "evreiski" (Jewish) which in Russian meant Yiddish spoken by the majority of the Ashkenazi Jews. But almost all the Jews of Kutaisi province were Georgian speakers. The prayers were recited in their synagogues in Hebrew but the lessons were read in the Georgian language, understandable to all of them. The Census of 1897 had revealed Georgian as the vernacular of just 23 percent of Jews in the same province which was a gross underestimation.

\section{Temporal context of the Population Census of 1926}

The above-mentioned mistake with the mother tongue was corrected 29 years later when the first All-Union General Population Census was carried out in the Soviet Union according to the situation on December 1, 1926 (Vsesoyuznaya perepis', 
1929). The materials of this Census are more accurate when tracing the historical settlement of the Jews in Georgia.

The Jewish settlement pattern in the first quarter of the $20^{\text {th }}$ century was fairly stable which was a result of the relative stability of economic policy in Georgia. A couple of comparisons of political and economic developments in Russia and Georgia will explain the reasons for such geographical inertia of the Jewish settlement pattern in Georgia.

After the Communist (Bolshevik) revolution of November 7, 1917, dramatic political and economic changes occurred in Russia proper including forcible nationalization of industrial enterprises, prohibition of private trade. The Russian currency, rouble, collapsed. These were the costs of "War Communism" practiced by the Bolsheviks in the early years of their rule. The economic dislocation in Russia was augmented by a bloody civil war (1918-1920) which led to a couple of million human victims. By 1921 Russia's economy was in ruins. The grave situation forced the ruling Communist Party of Russia (Bolsheviks) under Lenin to turn to a "New Economic Policy" (NEP) which was introduced in the Russian Soviet Federated Socialist Republic (RSFSR) in the spring of 1921. NEP allowed private trade and other small and medium business to restart in the country. Forcible expropriation of agricultural products from peasants by the state, which was a common practice in the first years of the Bolshevik rule, was abandoned. Real money ("chervonets") was introduced.

Georgia was a part of the Russian Empire from 1801/1811 until 1917 when there was legal to own private property. Being the independent Democratic Republic in 1918-1921 Georgia avoided the Russian "War Communism" and civil war. A liberal economic policy allowing private commerce had been followed by the ruling SocialDemocratic Workers' Party of Georgia (the Mensheviks) in 1918-1921. As an American scholar R.G. Suny wrote: "The Mensheviks held back from assaults on the capitalist mode of production" (Suny, 1994, 201). After the intervention of the Russian Red Army Georgia was proclaimed a Soviet Socialist Republic (SSR) on February 25, 1921. From a political point of view that meant the introduction of an authoritarian regime, the prohibition of all parties except the Communist one, sharp degradation of democracy, arrest, and execution of dissenting and often innocent people. Large industrial enterprises (very rare in the predominantly agricultural Georgia) were nationalized. But because NEP was extended to the SSR Georgia ${ }^{3}$ and other non-Russian Soviet republics in 1921 agricultural production and commerce remained in private hands. That was suitable to the Jewish population of this country as the majority of them were engaged in wholesale and retail trade, artisanship, or agriculture.

NEP proved to be an economic success in the USSR, but from ideological and political points of view, it was considered a potential threat to the only party which monopolized political power - the Communist one, with its ideology based on class struggle. The revival of wealthy classes was perceived as a prerequisite of more economic power in their hands which might have transformed into political power later. Stalin who after Lenin's death in 1924 gradually became the paramount leader of the USSR abolished NEP altogether in 1928. Enterprises of any size and large residential houses were nationalized. Private trade had been declared illegal. This

\footnotetext{
${ }^{3}$ Such sequence of words - "Soviet Socialist Republic [of] Georgia" - was used in the official name of the Soviet republic until 1936 when it was renamed the Georgian SSR.
} 
gravely affected the economic situation of the Jewish population of Georgia (Baazova, 2016, 685).

But all the above-mentioned happened after the 1926 Population Census had been carried out, and before 1928 the Jewish settlement pattern had no incentives to change dramatically. There was the outflow of the rural Georgian Jewish population to large cities, especially to Tiflis even before the abolition of NEP, but migration to urban centers of Georgia intensified from the 1930s. Nevertheless, the majority of the Jewish households remained in the same settlements as in 1926 up to the late 1960s when the Great Aliyah (see below) started and the traditional network of Jewish settlements in Georgia ceased to exist.

It can be argued that the most detailed Population Census carried out in the Soviet times was that of 1926. Its published materials provided information on number, sex ratio, ethnic and subethnic division, and mother tongue of population according to towns, townships, and rural communities. In contrast, the published materials of most of the Censuses of Population carried out later in the USSR $\left(1937^{4}, 1939,1959,1970\right.$, 1979, 1989) don't provide a geographer with detailed spatial information, as these materials do not contain data about the population of rural communities. Even the information about the number of population of towns with less than 50,000 inhabitants became top secret in the USSR since the early 1970s.

The results of all Censuses of the population in the USSR ignored the religious affiliation of a person as the Communist regime insisted on its atheistic character. The Jews of the Soviet Union were considered as an ethnic group (narodnost') and not a religious one. The Communist state's antireligious propaganda and practices in the 1920s-1930s were pointed against all the religious denominations, including Jewish. But the restrictions against the latter were a bit milder in Soviet Georgia than in the USSR as a whole. It wasn't allowed to construct new synagogues: almost all the synagogues in Soviet Georgia were constructed before 1921, e.g. in Lailashi in 1800, in Senaki - 1818, in Akhaltsikhe - 1860 and 1880, in Tbilisi-1864, 1885, and 1886, etc. (Baazova, 2016, 751-765). Some of them were closed the same way as in the USSR as a whole, but an official document of 1946 reveals that among the 30 acting synagogues in Georgia one, in the town of Gori, had been built in 1937 (Baazova, 2016, 752), apparently after the permission obtained from the local administration. Several synagogues in Soviet Georgia were refurbished thanks to insistence of the leaders of the Jewish congregations.

The majority of synagogues in contemporary Georgia stay closed because the practicing believers moved elsewhere, but they serve as markers of the past Jewish settlement. The buildings of a number of synagogues had been restored to serve as historical monuments with the financial aid of an ethnic Georgian philanthropist B. Ivanishvili in 2013-2014.

\footnotetext{
${ }^{4}$ The results of the All-Union Population Census carried out in January 1937 didn't satisfy Stalin as they revealed a dramatic decline of population in Ukraine, Kazakhstan, and parts of RSFSR caused by terrible famine following forcible collectivization of peasant households in 1931-1933. The organizers of the Census were sentenced to death. The results were declared null and void and made secret. Generalized data of the All-Union Population Census of 1937 became public only in 1990 [Polyakov et al., 1990].
} 


\section{The Jews of Georgia according to the Census of Population of 1926}

30,632 persons (1.15 percent of 2,666,494 people of SSR Georgia) were Jewish in 1926. The total number of Jews in Georgia increased by 70 percent from 1897 to 1926. Apart from the high birth rate, the immigration of Ashkenazi Jews from the other parts of Russia/USSR contributed to such growth.

30,632 persons ( 1.15 percent of 2,666,494 people of SSR Georgia) were Jewish in $1926 .{ }^{5}$ The total number of Jews in Georgia increased by 70 percent from 1897 to 1926. Apart from the high birth rate, the immigration of Ashkenazi Jews from the other parts of Russia/USSR contributed to such growth.

The All-Union Population Census of 1926 divided the Jews of the Soviet Union according to six subgroups. As for SSR Georgia, 20,897 claimed to belong to the subgroup of the Georgian Jews, 9,262 - were Jews ("Evrei" - this referred to Ashkenazi Jews who were addressed commonly by the local population as "Russian Jews"), 176 - Crimean Jews, 145 - Central Asian ("Bukhara") Jews, 98 - Karaits, and 54 - Mountain Jews (of Dagestan and Azerbaijan). The latter four subgroups were small in number in Georgia and didn't form significant communities. Therefore, only the geography of the Georgian and Ashkenazi Jews in Georgia will be analyzed below.

Georgian Jews made up 68.2 percent of the total Jewish population of Georgia. They exclusively (99.9 percent) claimed Georgian as their mother tongue: this reveals a serious flaw of the 1897 Census of Population mentioned above. Ashkenazi Jews made up 30.2 percent of all the Jews of Georgia. 53.2 percent of them considered Russian as their mother tongue, 41.5 percent - "the language of their nationality" (most probably that was Yiddish), 3 percent - Georgian. The rest declined to answer.

It is to be mentioned that the mixed marriages of the Georgian and Ashkenazi Jews were rather rare. The Georgian Jews adhered to endogamy, followed a stricter form of religion, and a more patriarchal way of life (Konstantinov, 2007). They were a bit critical of "emancipated" Ashkenazi women. ${ }^{6}$ There was more chance for an Ashkenazi woman to marry a man of a different ethnicity than a Georgian Jewish man and there were quite a few mixed families of the Ashkenazi Jews and representatives of other ethnic groups (Georgians, Russians, Armenians, etc.) in urban centers of Georgia. A certain part of the descendants of such mixed families remembered their Jewish roots when emigration to Israel became advantageous in the last decades of the $20^{\text {th }}$ century.

The socio-political life of Georgia's Jewry in the 1920s ought to be discussed in the context of the USSR as a whole. Although Bolshevik revolution inflicted a harsh blow to democracy, among its rather rare positive accomplishments is to be mentioned the abolition of anti-Jewish practices of the Tsarist regime: e.g. the Pale of the settlement was erased, quotas for university admission were canceled. In the 1920s the Jews had ample opportunities for education, employment, and career advancement.

\footnotetext{
${ }^{5}$ All statistics below including those displayed in tables are given per the results of the AllUnion Population Census of 1926 [Vsesoyuznaya perepis', 1929] if not specified otherwise.

${ }^{6}$ The author recalls that in 1999 when serving as the Ambassador of Georgia in Israel, he attended in the city of Ashdod playing of a comedy with a peculiar name "Ashkenazi wife" written in Georgian by an Israeli playwright of Georgian Jewish origin. The comedy was met warmly by the audience composed of the Georgian Jews.
} 
Ashkenazi Jews of Russia proper were quick to take advantage of such opportunities. Some of them reached very high levels of the hierarchy of the ruling Communist Party (Bolsheviks), especially in the early years of Soviet Russia: the names of such prominent Soviet leaders of Jewish descent as Trotsky, Sverdlov, Kamenev, Zinoviev, Sokolnikov, Litvinov, Kaganovich, Larin, etc. come to memory.

According to V. Konstantinov the Jews composed 5 percent of the members of the All-Union Communist Party (Bolsheviks) in the first half of the 1920s while they constituted just 1.8 percent of the entire population of the USSR (Konstantinov, 2007, 254). This indirectly indicates to their substantial role in the internal political life of the state as a whole. In contrast, the Jews composed just 0.8 percent of the members of Communist Party of Georgia (ibid.) which was a regional organization of the allUnion Communist Party (Bolsheviks). It is impossible to determine what were the shares of Georgian and Ashkenazi Jews in the above "0,8 percent", but most likely Ashkenazi Jews prevailed.

Ashkenazi Jews were better educated in general in 1926: 73.6 percent of them were literate; the level of literacy of the Georgian Jews was lower (38 percent among males and 27 percent among females). Meanwhile, the educational level of the Georgian Jews was rising. That primarily concerned the residents of Tbilisi, where more Georgian Jews began to migrate from the 1920s. During the later decades of the $20^{\text {th }}$ century the Georgian Jews got more involved in the cultural fabric of Georgia as many of them got university degrees and started activities in such spheres, which were unknown to their immediate ancestors: some of them became prominent in sciences, arts, medicine, law, Georgian literature, etc.

It ought to be noted that the Ashkenazi Jews were not represented among the intelligentsia of Soviet Georgia at the same high level as, say in Soviet Russia or Soviet Ukraine because most of them didn't know Georgian language and, besides, the Georgian intelligentsia (including that of Georgian Jewish origin) was quite numerous itself.

\section{Geography of Jewish settlement in 1926}

The Administrative-Territorial Division (ATD) of Georgia in the 1920s was different from the one introduced in 1930 which is used since with minor changes. The country was using a somewhat modified ATD of the independent Democratic Republic of Georgia in 1926 with new autonomous units established. SSR Georgia was divided into 24 districts (mazra in Georgian, uezd in Russian) mostly bearing the name of its center (apart of the districts of Kodori, Racha, Lechkhumi, Zemo Svaneti, and Borchalo) of which five were in the Treaty SSR of Abkhazia ${ }^{7}$, five - in the Autonomous SSR of Adjara. South Ossetian Autonomous Region (SOAR), established in 1922, had no district division but was divided into 14 rural raions. The capital Tbilisi and the seaport of Poti had separate administrative statuses (fig.1).

\footnotetext{
${ }^{7}$ Abkhazia with a population less than 200,000 in 1926 was the only "Treaty Soviet Socialist Republic" in the USSR formally "associated to the SSR Georgia by a treaty" from 1921. The clause 15 of the Constitution of the USSR of 1924 considered Abkhazia as an autonomous republic within the SSR Georgia (Konstitutsia, 1924) which sent just one member to the Chamber of Nationalities of the Central Executive Committee of the USSR in Moscow while the Union republics sent five representatives each. The actual status of Abkhazia as an Autonomous Republic within SSR Georgia became official from February 1931.
} 
Districts included cities/towns, townships ${ }^{8}$, and rural communities. The rural community had the traditional name of temi in Georgian language (the same transcription was used in the Russian text of the results of the All-Union Population Census of 1926 in the SSR Georgia). Temis, 525 in all (including 14 rural raions of SOAR), encompassed the neighbouring villages and hamlets with strong cultural and social links.

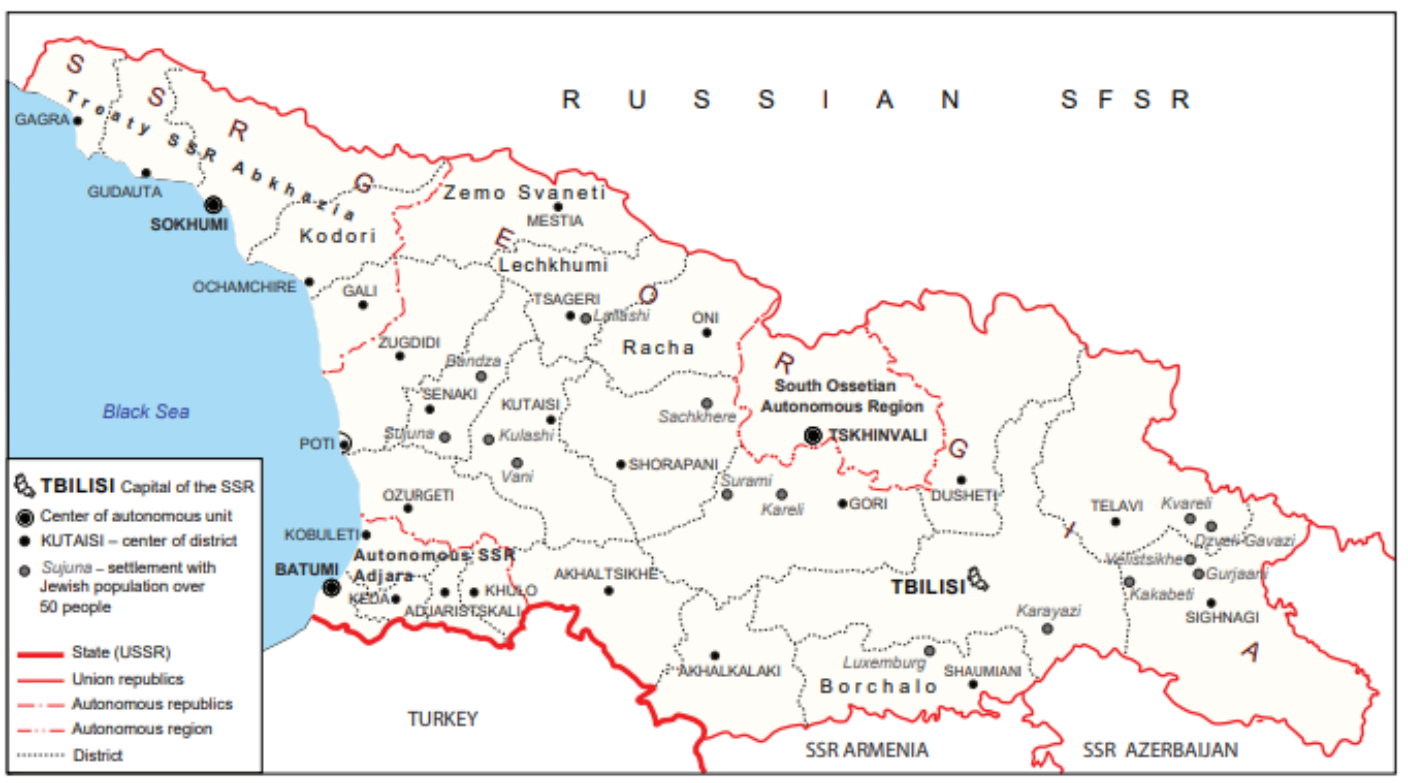

Fig. 1. Administrative-territorial division of Soviet Georgia in 1926 and settlements (other than administrative centers) with Jewish population over 50 people

Fig. 2 shows the placement of Ashkenazi and Georgian Jews according to urban and rural settlements of Georgia in 1926. The Jewish population was represented in the relatively more developed Intermountainous Lowland of Georgia located in the central parts of Eastern and Western Georgia (Gachechiladze, 1995), while to the north and south of the country there were economically less developed mountainous regions. Nevertheless, large Jewish communities were present in some mountainous districts of Georgia (town of Oni, rural community of Lailashi).

The Georgian Jews that had no problems of the linguistic contact with the ethnic Georgian majority, were fairly scattered and represented in several dozens of settlements of Georgia in 1926 but only in 25 of them, their number exceeded 50 people (table 2). There were more settlements with smaller number of the Jewish population.

72.9 percent of Jews were urban dwellers that far exceeded the level of urbanization of those days Georgia (22 percent). 59,9 percent of all the Jewish population (divided almost evenly between the Ashkenazi and Georgian Jews) were residing in the largest urban centers of Georgia - Tbilisi, Kutaisi, Batumi, Sokhumi, Poti, Akhaltsikhe, and Gori. The rest of urban population lived in the towns and townships with a population of less than 10 thousand whose inhabitants, including local Jews, at least partially were engaged in agriculture (Jaoshvili, 1968).

\footnotetext{
${ }^{8}$ The status of city/town (kalaki in Georgian) and township (daba) was granted by the state and didn't depend on the number of population.
} 


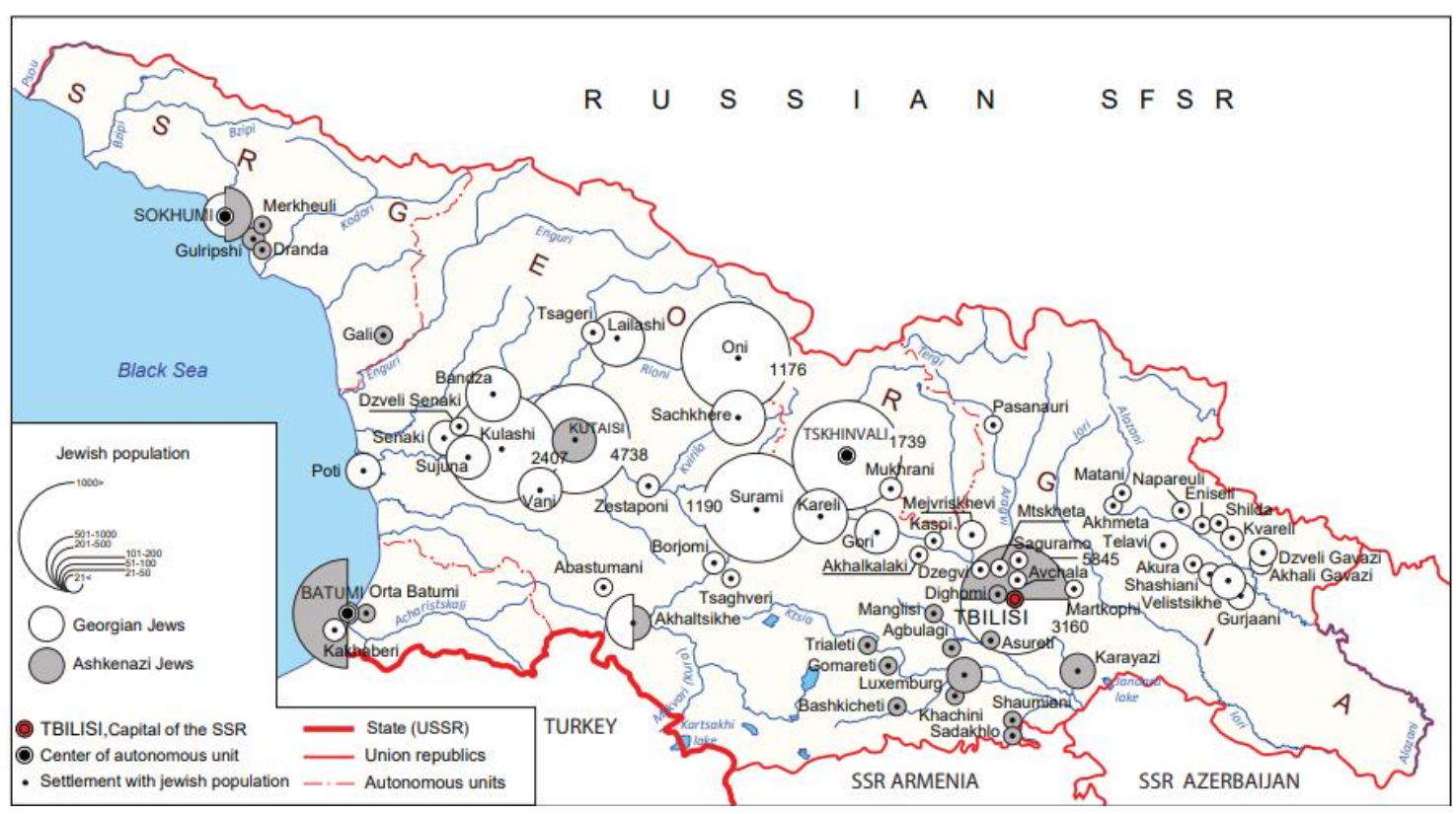

Fig. 2. Jewish population in urban and rural settlements of SSR Georgia in 1926

Table 2. The number of the Jewish population and their share in the entire population of selected cities (c), towns ( $t$ ), townships (tn) and rural communities/temi (rc) in 1926

\begin{tabular}{|c|r|r|r|r|}
\hline Settlement & $\begin{array}{c}\text { Entire } \\
\text { population }\end{array}$ & $\begin{array}{c}\text { Number of } \\
\text { the Jewish } \\
\text { population }\end{array}$ & $\begin{array}{c}\text { Of them } \\
\text { Georgian } \\
\text { Jews }\end{array}$ & $\begin{array}{c}\text { Share of all } \\
\text { the Jews in } \\
\text { the entire } \\
\text { population of } \\
\text { the settlement }\end{array}$ \\
\hline Tbilisi (c) & 294,044 & 9,005 & 3,160 & 3.1 \\
\hline Kutaisi (c) & 48,196 & 4,982 & 4,738 & 10,3 \\
\hline Kulashi (rc) & 9,424 & 2,407 & 2,407 & 25.5 \\
\hline Batumi (c) & 48,474 & 1,988 & 37 & 4.1 \\
\hline Tskhinvali (t) & 5,818 & 1,781 & 1,739 & 30.6 \\
\hline Surami (tn) & 4,589 & 1,190 & 1,190 & 25.9 \\
\hline Oni (t) & 2,912 & 1,176 & 1,176 & 40.4 \\
\hline Sachkhere (tn) & 2,757 & 983 & 983 & 35.7 \\
\hline Sokhumi (c) & 21,568 & 974 & 215 & 4.5 \\
\hline Akhaltsikhe (t) & 12,327 & 921 & 827 & 7.5 \\
\hline Kareli $(\mathrm{rc})$ & 8,707 & 784 & 784 & 9.0 \\
\hline Bandza (rc) & 5,906 & 677 & 677 & 11.5 \\
\hline Lailashi (rc) & 3,519 & 533 & 533 & 15.1 \\
\hline Sujuna (rc) & 6,144 & 499 & 499 & 8.1 \\
\hline Vani $(\mathrm{rc})$ & 10,709 & 412 & 412 & 3.9 \\
\hline Gori $(\mathrm{t})$ & 10,547 & 314 & 314 & 3.3 \\
\hline Poti $(\mathrm{t})$ & 13,137 & 161 & 161 & 1,2 \\
\hline Velistsikhe (tn) & 5,934 & 127 & 127 & 2.1 \\
\hline
\end{tabular}


Georgian Geographical Journal.

\begin{tabular}{|c|r|r|r|r|}
\hline Senaki (tn) & 5,498 & 118 & 118 & 2.1 \\
\hline Telavi (t) & 9,697 & 100 & 100 & 1.0 \\
\hline Mukhrani (rc) & 8,696 & 89 & 89 & 1.0 \\
\hline Dzveli Gavazi (rc) & 8,269 & 79 & 97 & 0.9 \\
\hline Luxemburg (tn) & 5,658 & 66 & 0 & 1.2 \\
\hline Karayazi (rc) & 8,358 & 55 & 0 & 0,7 \\
\hline Gurjaani (rc) & 10,345 & 51 & 51 & 0,5 \\
\hline
\end{tabular}

The city of Tbilisi (Tiflis of those days) was the capital not only of the SSR Georgia but also of the Transcaucasian Soviet Federated Socialist Republic (TSFSR) which existed in 1922-1936. The TSFSR included three Soviet republics of the South Caucasus - Armenia, Azerbaijan, and Georgia whose major ethnic groups Armenians, Azeris, and Georgians - spoke mutually unintelligible languages belonging to different linguistic families. Multinational bureaucracy of the TSFSR used Russian as lingua franca. That might have been a reason for coming from the European part of the USSR of quite a few Ashkenazi Jews whose majority had good proficiency in Russian. Many Ashkenazi Jews found a job in the governmental sector (e.g. bureaucracy, state security) but also in medical service, freelance activities of the multiethnic Transacaucasian capital. They made up 1.9 percent (5706 persons) of the entire population of the city: their number doubled in comparison with that in 1897 (2868). They almost twice exceeded the number of the Georgian Jews in the city in 1926. But growth of the number of the latter from 411 in 1897 to 3160 in 1926 was outstanding: their number increased more than sevenfold! Other subgroups of Jews accounted for mere 139 persons in the city. Although Tbilisi possessed Jewish districts in Kala area in the old part of the city (Jones, 2005, 164) around synagogues, the Jewish newcomers, especially Ashkenazi Jews who arrived from Russia or Ukraine, preferred to settle in the other parts of the city.

The population of the city of Kutaisi was almost monoethnic and entirely Georgian-speaking: 82.2 percent were ethnic Georgians and the largest minority were Georgian Jews (10.3 percent) communicating in the same language. Kutaisi had the second-largest community of Jews in Georgia after Tbilisi. There were three synagogues in Kutaisi.

The majority of Jews were Ashkenazi in Batumi and Sokhumi (the capitals respectively of Adjara and Abkhazia) on the Black Sea coast of Georgia. Ashkenazi Jews far exceeded the number of Georgian Jews in both cities (the latter made up just 217 in Sokhumi, and 37 - in Batumi). The largest in Georgia number (206) of the Jews of other than Georgian Jewish and Ashkenazi subgroups was present also in Sokhumi.

Ashkenazi Jews together with ethnic Russians and people of other origins from the European part of Russia started to settle in the fast-developing seaport of Batumi after the latter was annexed by the Russian Empire in 1878: earlier it belonged to the Ottoman Empire (in medieval times - to the Georgian Kingdom). Over one thousand Ashkenazi Jews were present in Batumi already at the end of the $19^{\text {th }}$ century. The rural area around the city was populated by Adjarans, an Islamized Georgian subgroup. Already in the first half of the $20^{\text {th }}$ century, the reintegration of Adjarans into the Georgian nation became an irreversible fact. Many of them moved from rural areas to the city of Batumi from the 1930s onward and gradually became a majority there. But in 1926 the population of the city of Batumi was clearly multiethnic. 


\section{Gachechiladze R.}

It was noticeable that the Jews were almost absent outside the centers of all the three autonomous units within SSR Georgia. That could be explained by cultural (in case of the Adjarans) or linguistic differences of rural ethnic minorities (in cases of the Abkhazians and Ossetians) from the Georgian Jews. In general, the rural areas of these autonomous units were underdeveloped in those days, peasants in the mountainous parts were mostly following subsistence agriculture.

23,5 percent of the Jews of Georgia resided in the medium and small towns and townships. In some of them (Oni, Sachkhere, Surami, Tskhinvali) Georgian Jews constituted the largest ethnic group after ethnic Georgians. In the small town of Oni (a historical province of Racha) which is on the way to the mountain pass leading to the North Caucasus, Georgian Jews (40 percent of the population of the town) had run trading business for generations. A beautiful synagogue (constructed in 1895) is a major architectural monument in the town even now.

The ancient Georgian town of Tskhinvali was added to the area allocated to the South Ossetian Autonomous Region established in 1922 to serve as its center. 30.6 percent of people in Tskhinvali were Jewish in 1926, the absolute majority of them Georgian Jews. Their number was slightly exceeded by ethnic Georgians (33.0 percent). The rest of the population were Ossetians (19.8 percent), Armenians (with the Georgian mother tongue, 14.2 percent), and Russians (1,9 percent).

A substantial Jewish population (26 percent of total) was in Surami (a historical province of Shida Kartli) located at the beginning of the long climb to the Rikoti pass on the highway leading from Eastern to Western Georgia and vice versa. The shops and catering establishments of the township located along the main road were visited by multiple travelers who usually stopped in Surami.

Akhaltsikhe (meaning "Newcastle" in Georgian) from medieval times was a traditional trading center of southern Georgia and always had a substantial Jewish population even when it was under the Ottoman rule (the $16^{\text {th }}$ century -1829). In 1873 there were 1972 Georgian-speaking Jews there (Sbornik, 1880). A small part of them together with the Jews from different areas of Georgia migrated to Ottoman Palestine in the late $19^{\text {th }}$ or early $20^{\text {th }}$ century and settled down in Jerusalem where they were addressed as "Gurji" (the word means "Georgian" in Turkish). More Jews from Akhaltsikhe moved to Tbilisi where they built a synagogue for themselves. Akhaltsikhe was the sixth in size urban settlement of Georgia in 1926 and the Jews (921 people, most of them Georgian-speaking) composed 7.5 percent of the entire population.

27.1 percent of Jews of Georgia were rural dwellers self-employed in agriculture (horticulture, sericulture, etc.) or involved in local commerce. They were present in 38 temis and in a handful of them their number exceeded 50 persons (table 2). Jews preferred to settle in the major village of a temi. All the villages with a sizeable Jewish population served as local "central places", having bazaars with multiple shops.

An article in Menora (Kekelia, 2020) confirms the above. It describes the life in the village of Bandza in Western Georgia during the times of NEP. The center of Bandza had a distinctive unofficial name of Uriakari which translates into English as "Jewish Gate". The majority of shops there belonged to the Jews who amounted to 677 people in 1926 (11,5 percent of the population of the temi). They were served by two synagogues built by the families of Sepiashvili and Ajiashvili in 1910 and 1915. Due to its convenient geographical location in the northern part of the Senaki district (a part of the historical province of Samegrelo), the village of Bandza served as a commercial center since the 1860 s for at least 17 smaller villages and hamlets in the 
vicinity which didn't possess a bazaar or even a shop. The Jews and Georgians maintained friendly relations which was typical of Georgia as a whole and the village of Bandza is a good example of such relations: Georgian Jews who emigrated to Israel from this village in the 1960-1970s or their descendants come annually to celebrate Passover there in their synagogues and to have traditional feasts together with the friends from local people.

The temi of Kulashi in the Kutaisi district (a part of Imereti province) had the largest number of the Georgian Jews in the rural area of the whole country: 2407 Jews of Kulashi constituted 25,3 percent of the total population of the temi. Almost all of them lived in the major village, Kulashi per se, where they had four acting synagogues and one - needing restoration. Some years after the Population Census of 1926 was conducted the village of Kulashi was granted an official status of a township.

In Kakheti, the easternmost historical province of Georgia comprising Telavi and Signaghi districts, famous for wine-making and other high-quality agricultural products, two rows of villages along the east and west banks of river Alazani could be observed on the map (fig. 2). Small groups (up to 25 people) of Georgian Jews were residing in these temis of Kakheti. Only in the town of Telavi, a township of Velistsikhe and large temis of Kvareli and Dzveli Gavazi the Jews made up communities of 50-125 persons. The Jews residing in Kakheti were producing kosher wine for the Jewish communities in Georgia (the largest consumer being their community in Tbilisi), supplying the population of Kakheti with manufactured goods, and buying local agricultural products to resell them in the towns of Georgia or elsewhere in the USSR.

A small cluster of the Ashkenazi Jews (just 102 persons) was present in Borchalo district (historical province of Kvemo Kartli and modern region of the same name to the south of Tbilisi). A possible explanation for the presence of the Ashkenazi Jews in this district might be the German population of the area. The Germans, predominantly from Württemberg, were settled in this part of Georgia by the government of the Russian Empire from 1817 onwards. In 1926 the Germans constituted an ethnic group of 12,074 people ( 0.5 percent of the total population of Georgia) residing mostly in the aforementioned district and the city of Tbilisi. They were well integrated into the economic structure of Georgia, at the same time preserving their language and culture. Supposedly the Ashkenazi Jews speaking Yiddish, very close to German, managed to find a contact with the local Germans. 66 persons of Ashkenazi Jewish origin resided in the township of Luxemburg ${ }^{9}$ where the majority of the population $(73.4 \%)$ were German-speakers.

\footnotetext{
${ }^{9}$ The name of the township during the Russian Empire and Democratic Republic of Georgia was Katarinenfeld in honor of Catherine II, Empress of Russia in the $18^{\text {th }}$ century, an ethnic German herself. In the Soviet era, the name had been changed to honor Rosa Luxemburg, a revolutionary socialist active in Germany who had been executed in Berlin, the Weimar Republic in 1919. After Nazi Germany invaded the USSR on June 22, 1941, all the persons of German origin residing in the European part of the USSR, including those in Soviet Georgia, were deported to Central Asia and Siberia by the order of the Kremlin. The township of Luxemburg was renamed and given the name of Bolnisi in 1943 after a nearby village famous for an ancient Georgian church of the $5^{\text {th }}$ century.
} 


\section{Jewish emigration and its geographical consequences}

The population dynamics of Georgia's Jews were upward until the end of the 1960s (table 3).

The largest number of Jews $(55,400)$ in Georgia appeared to be in 1970 when they made up 1.2 percent of the entire population. But by that time huge repatriation of the Jews to Israel had already started (Gachechiladze, 2012). The process received the name of Great Aliyah of Georgian Jews, literally "the act of going up (to Jerusalem)".

Table 3. Dynamics of Jewish Population of Georgia according to the Population Censuses of 19262014 (thousands) 10

\begin{tabular}{|c|c|c|c|c|}
\hline $\begin{array}{c}\text { Census } \\
\text { year }\end{array}$ & $\begin{array}{c}\text { All Jews } \\
\text { of } \\
\text { Georgia }\end{array}$ & $\begin{array}{c}\text { Among } \\
\text { them the } \\
\text { Georgian } \\
\text { Jews }\end{array}$ & $\begin{array}{c}\text { Jews } \\
\text { residing in } \\
\text { Tbilisi }\end{array}$ & $\begin{array}{c}\text { The ratio of Jews } \\
\text { residing in Tbilisi } \\
\text { in the total of the } \\
\text { Jews of Georgia } \\
\text { (percent) }\end{array}$ \\
\hline 1926 & 30,6 & 21,0 & 9,0 & 29,4 \\
\hline 1939 & 42,3 & 27,0 & 13,9 & 32,9 \\
\hline 1959 & 51,6 & 40,0 & 17,9 & 34,7 \\
\hline 1970 & 55,4 & 45,0 & 19,6 & 35,4 \\
\hline 1979 & 28,3 & 18,0 & 14,9 & 52,7 \\
\hline 1989 & 24,8 & 19.0 & 13,5 & 54,4 \\
\hline 2002 & 3,7 & $\ldots$ & $\ldots$ & $\ldots$ \\
\hline 2014 & 1,4 & $\ldots$ & $\ldots$ & $\ldots$ \\
\hline
\end{tabular}

... no data; Sources: Konstantinov, 2007; Vsesoyuznaya perepis'1929; Sakartvelos mosakhleobis, 2003; Mosakhleobis 2014

Based on different sources V. Konstantinov, $(2007,272)$ calculated the number of Jews who emigrated from the USSR by Union Republics. According to his estimates 29,900 Jews emigrated from Georgia in 1959-1978 (28,000 in 1969-1972 alone): that figure constituted 16,3 percent of all the Jews that left the USSR at the same time. By the end of the 1970s, the Georgian Jews left all rural areas and many small towns and townships of Georgia. Kulashi, Tskhinvali, Oni, Surami, Akhaltsikhe, Kareli, Bandza, Lailashi, Sujuna, Vani, Senaki, and other small settlements lost all their Jewish population (Gachechiladze, 2011, 406). The number of Jews in Georgia diminished dramatically.

The major factor for mass emigration was the Zionist principle. In the rural settlements, the leaders of Jewish congregations insisted on the necessity of Aliyah. A lot of families decided to emigrate taking into account the decision of the entire community. Many people were afraid to "stay alone" when "everybody is leaving". A strong pull-factor of migration was economically fast developing State of Israel.

10 The data for 1939-1989 in column 3 of table 3 are based on the estimates given by V. Konstantinov (2007, tables 1.2, 1.5, 1.6) where 32,000 Georgian Jews in 1939 were mentioned. But such a number implied an increase of this group by an improbable 50 percent (sic!) in 1926-1939 due to natural growth only as the inflow of the Georgian Jews from outside of the Georgian SSR was excluded: practically all of them resided in this Union republic in the 1930s. A more plausible estimate is closer to 27,000 Georgian Jews in 1939 which was used in the table 3 . 
Soviet Jews enjoyed unique opportunity in 1969-1972 to leave the USSR which was a cherished desire of many Soviet citizens of other nationalities as well, which, like Jews, would like to take advantage of the benefits of Western prosperity. There have been quite a few cases of fictitious marriages of non-Jews with Jews in order to obtain permission to leave the USSR and eventually to travel to the USA.

Due to new restrictions introduced by the Soviet government during the decade of 1979-1988, the volume of Jewish emigration from Georgia decreased and only 4,800 of them left: 3,300 for Israel and 1,500 for the US (Konstantinov, 2007, 272).

It looks like there was an indirect factor to some extent hindering emigration. The USSR unofficially banned the right to return to Jewish emigrants if they decided to apply for Soviet citizenship again. Some potential emigrants took seriously the issue. That might be a geographical explanation of why a substantial part of the Jews, better educated and rather wealthy people (some of them involved in "shadow economy"), remained in the large cities of Georgia, especially in Tbilisi: they didn't want to risk their relatively prosperous present in the USSR for an unknown future abroad. Table 4 reveals that in the 1970s-1980s more than half of the Jews of Georgia lived in Tbilisi (54,4 percent in 1989). The capital city accommodated more than a million of inhabitants of different ethnic origin 65 percent of them being ethnic Georgian in 1989 (Gachechiladze, 1995, 75) with whom the Georgian Jews maintained the closest relations.

But the political and economic situation in the USSR was changing rapidly on the eve of the 1990s. The Soviet superpower was on the brink of collapse. Nationalliberation movements were becoming more powerful in the Baltic republics, Georgia, and Ukraine. There was already a war raging between the Soviet republics of Armenia and Azerbaijan over the region of Nagorno Karabakh. Political parties multiplied in Georgia as elsewhere in the Union republics, some having armed militias very much resembling criminal gangs. Illegal guns became easily accessible. Many people, not only Jews, were leaving the USSR and its successor states for good since the early 1990s.

According to Konstantinov $(2007,272)$ about a million former Soviet Jews emigrated to Israel in 1990-2006. A small part of them, 22,600, was from Georgia but they constituted the majority of the remaining community. Besides, 2,000 Jews of Georgia left for the US and 300 - for Germany [ibid.].

The Censuses of the Population of independent Georgia, a member of the UN from July 1992, were conducted by the Statistical Office of this country in the $21^{\text {st }}$ century. "Religious affiliation" had been included in the questionnaires of the Censuses of Population of 2002 and 2014. 3,700 Jews were registered by the Census of Population of Georgia in 2002 (Sakartvelos mosakhleobis, 2002).

The results of the General Census of Population of Georgia of 2014 didn't mention the Jews in the table of ethnic groups: because of the small number they were included in the category of "Others" (Mosakhleobis 2014). But 1,4 thousand people were mentioned as followers of Judaism in the table of religious affiliations. These were the Jews of Georgia in 2014. That number doesn't include the descendants of the mixed families who theoretically have a right to apply for Israeli citizenship.

Although small in number, the Jewry of Georgia, mostly residing in Tbilisi, was aging but still viable community in the first decades of the $21^{\text {st }}$ century. They were served by two synagogues and a community house in Tbilisi. Two Jewish newspapers (in Georgian and Russian) were being published. The Jewish Historical- 
Ethnographical Museum had been restored with the help of the government of Georgia.

The Georgian Jews who emigrated to Israel, continue to maintain community spirit there. They have constructed their synagogues in Jerusalem, Ashdod, Holon, Kiryat Ata, Bat Yam, etc. Some of them tend to visit the places in Georgia where their ancestors used to live.

\section{Conclusion}

For the first time, the results of the All-Union Population Census of 1926 in the Georgian SSR were analyzed from the historical-geographical point of view to describe the settlement pattern of a relatively small ethnoreligious group, the Jews, in the 1920 s.

Over two-thirds of the Jews belonged to a subgroup of Georgian Jews who used to live in Georgia from times immemorial. They constituted a large proportion of the population in several small towns and townships (Tskhinvali, Oni, Sachkhere, Surami) located on major transportation routes and were present in the better developed rural areas.

Almost one-third of the Jews were Ashkenazi who started to migrate to Georgia from the beginning of the $19^{\text {th }}$ century. They resided predominantly in the largest urban centers.

The settlements with a large number of Jewish population in rural area of Georgia and some small towns served as local trading centers in the 1920s. The majority of Jews there were involved in commerce which was mostly in private hands during the so-called New Economic Policy carried out in the Soviet Union in 1921-1928.

The dynamics of Jewish population from the 1920s until the end of the 1960s were upward. But from the 1970s the number of Jews was declining due to emigration to the State of Israel. The majority of the remaining people concentrated in Tbilisi, the capital of Georgia.

From the early 1990s, the Jewish emigration became massive and their settlement network in Georgia practically ceased to exist. A small Jewish community remained in Tbilisi in the first decades of the $21^{\text {st }}$ century.

\section{Acknowledgments}

The author would like to express his gratitude to Ms. Tamara Chichinadze of Vakhushti Bagrationi Institute of Geography (Tbilisi State University), for drawing the maps for this text, Professor Stephen F. Jones of Mount Holyoke College (MA, USA), Professor Constantine Lerner of the Hebrew University of Jerusalem (Israel), and Mr. Guram Batiashvili, Editor-in Chief of the newspaper "Menora" (Tbilisi, Georgia) for useful advice.

\section{References}

Baazova, Lili. (2016). Evrey v Gruzii [Jews in Georgia]. Moscow: Galaktika (in Russian)

Gachechiladze, Revaz (2011). ahklo ahgmosavleti: sivrtse, khalkhi da politika [The Middle East: Space, People, and Politics] III edition. Tbilisi: Sulakauri Publishing (in Georgian)

Gachechiladze, Revaz (2012). didi alia. enciklopedia "sakartvelo". tomi 2 [Great Aliyah. In: Encyclopedia "Georgia", vol. 2] Tbilisi: Georgian Encyclopedia Publication (in Georgian)

Gachechiladze, Revaz (1995). The New Georgia: Space, Society, Politics. London: UCL Press 
Jaoshvili, Vakhtang (1968). Naselenie Gruzii. Ekonomiko-geograficheskoe issledovanie. [Population of Georgia. An economic-geographical study] Tbilisi: Metsniereba (in Russian)

Jones, Stephen F. (2005). Socialism in Georgian colors. The European Road to Social Democracy 1883-1917. Cambridge, Mass., London: Harvard University Press

Kartlis tskhovreba. Teksti dadgenili qvela dziritadi khelnatseris mikhedvit s. qaukhchishvikis mier. Tomi I (1955). [A history of Kartli/Georgia. The text was established by S. Kaukhchishvili according to all major manuscripts. Volume I]. Tbilisi: Sakhelgami (in Georgian)

Kartuli istoriuli sabutebis korpusi. Tomi I. (1984). Sheadgines da gamosacemad moamzades t. enukidzem, v. silogavam da n. shoshiashvilma [Collection of the Historical Georgian Documents. Vol. I. Collected and prepared for publication by T. Enukidze, V. Silogava, and N. Shoshiashvili] Tbilisi: Metsniereba (in Georgian)

Kekelia, Igor. (2020). sopel bandzis savachro-puladi urtiertobis istoriidan (XIX s-is meore naxevari - XX s-is pirveli naxevari [From the history of trade-financial relations in the village of Bandza (II half of XIX c. - I half of XX c.) In newspaper Menora N9, August (in Georgian)

Khananashvili, Daniel (2002-2003). ebraelebi sakartvelos daba-kalakebshi [The Jews in Georgia's towns and townships]. In newspaper Menora NN 18-24, 2002 - NN 1-12, 2003 (in Georgian)

Konstantinov, Vyacheslav. (2007). Evreiskoe naselenie bivshego SSSR v XX veke (social'nodemograficheskii analiz) [Konstantinov, Vyacheslav. The Jewish population of the former USSR in XX century (social-demographic analysis). Jerusalem: Lira (In Russian)

Konstitutsia SSSR (1924). Izdatel'stvo Tsentral'nogo Komiteta N81. Tiflis [Constitution of the USSR. Publishing House of the Central Committee N81] (In Russian)

Lerner, Constantine B. (2008) Evrei Gruzii ot Ellinizma do pozdnego Feodalizma [The Jews of Georgia. Since Hellenistic Times till The Late Feudal Period (II BC -XIX AD), Jerusalem: Magnes Press (in Russian)

Mamistvalishvili, Eldar (1995). Kartvel ebraelta istoria. Antikuri da feodaluri khana [A history of the Georgian Jews. The period of antiquity and feudalism]. Tbilisi: Metsniereba (In Georgian)

Mosakhleobis 2014 wlis sakoveltao aghtseris. dziritadi shedegebi. Zogadi informatsia (2016). [Main results of the General Census of Population of 2014. General information]. Tbilisi: National Service of Statistics. $\quad$ Retrieved from http://census.ge/files/results/Census\%20Release_GEO.pdf (August 20, 2020)

Pervaya vseobshchaya perepis naselenia Rossiiskoy imperii 1897 goda. Tom II (1905) [The First General Census of the Population of the Russian Empire. Volume II]. Saint-Petersburg] (in Russian)

Polyakov Yu. A., Zhiromskaya V. B., Kiseliov I. N. (1990). Polstoletiya bezmolviya. Vsesoyuznaya perepis' naseleniya 1937 goda. [Half a century of silence. All-Union Population Census of 1937]. In the journal Sotsiologicheskie issledovanya [Sociological studies] №7, pp. 30-52 (in Russian)

Sakartvelos mosakhleobis 2002 tslis pirveli sakoveltao aghtseris shedegebi. tomi I (2003) [The results of the First National Population Census of Georgia of 2002. Vol I] Tbilisi: State Department of Statistics of Georgia. Retrieved from http://census.ge/files/2002/geo/I\%20tomi.pdf (August 20, 2020)

Sbornik svedenii o Kavkaze. Tom VII. (1880). [Collection of information on the Caucasus. Volume VII]. Printing house of the Central office of the Caucasian Viceroy. Tiflis (in Russian) 
Suny, Ronald Grigor (1994). The Making of the Georgian Nation. Indiana University Press: Bloomington and Indianapolis

Vsesoyuznaya perepis' naselenia 1926 goda. SSR Gruzia. Otdel I: narodnost' - rodnoy yazik - vozrast - gramotnost' (1929); Izdanie centr. stat. upravleniya ZakSFSR. Tiflis [All-Union Census of Population of 1926. SSR Georgia. Part I: ethnicity - mother tongue - age - literacy. Publication of Central Statistical Office of TSFSR. Tiflis] (in Russian and Georgian) 